\title{
Bionic-inspired Construction of Zn(4,4'-dipy) (OAc)2/Bacterial Cellulose Composite Membrane for Efficient Separation Synergistically Adsorption of Nitrogen and Phosphorus
}

\author{
Xudong Zheng ( $\nabla$ zheng@cczu.edu.cn ) \\ Changzhou University \\ Wen Sun \\ Changzhou University \\ Ning Wei \\ Changzhou University \\ Tingting Bian \\ Changzhou University
}

\section{Yi Zhang}

Changzhou University

Lingli Li

Changzhou University

Yuzhe Zhang

Changzhou University

Zhongyu Li

Changzhou University

Hongxiang Ou

Changzhou University

\section{Research Article}

Keywords: Phosphorus, Ammonia nitrogen, Adsorption, Bacterial cellulose, Membrane, Tannic acid

Posted Date: March 16th, 2021

DOI: https://doi.org/10.21203/rs.3.rs-295433/v1

License: () (1) This work is licensed under a Creative Commons Attribution 4.0 International License.

Read Full License 


\title{
Bionic-inspired Construction of $\mathrm{Zn}\left(4,4^{\prime}\right.$-dipy)(OAc) 2 /Bacterial Cellulose Composite
} Membrane for Efficient Separation Synergistically Adsorption of Nitrogen and

\author{
Phosphorus
}

Xudong Zheng ${ }^{\mathrm{a} *}$, Wen Sun ${ }^{\mathrm{a}}$, Ning Wei ${ }^{\mathrm{a}}$, Tingting Bian ${ }^{\mathrm{a}}$, Yi Zhang ${ }^{\mathrm{a}}$, Lingli Li ${ }^{\mathrm{a}}$, Yuzhe Zhang ${ }^{\mathrm{a}}$, Zhongyu $\mathrm{Li}^{\mathrm{a}}$, b, c , Hongxiang $\mathrm{Ou}^{\mathrm{a} *}$

\footnotetext{
${ }^{\text {a }}$ School of Environmental \& Safety Engineering, Changzhou University, Changzhou 213164, PR
}

China

${ }^{\mathrm{b}}$ Jiangsu Key Laboratory of Advanced Catalytic Materials and Technology, School of Petrochemical Engineering, Changzhou University, Changzhou 213164, PR China

${ }^{\mathrm{c}}$ Advanced Catalysis and Green Manufacturing Collaborative Innovation Center, Changzhou University, Changzhou 213164, PR China

* Corresponding author. Mail address: zheng@cczu.edu.cn Postal address: Mingxing Building, Science and Education City, Wujin District, Changzhou, Jiangsu, China 


\section{Abstract}

Phosphorus and nitrogen flow to water leads to eutrophication and depletion of reserves. Bionic-inspired tannin modification is proposed for preparing a tanninmodified La- $\mathrm{Zn}\left(4,4^{\prime}\right.$-dipy $)(\mathrm{OAc})_{2} /$ bacterial cellulose composite membrane for simultaneous adsorption of total phosphorus and ammonia nitrogen in water. Its physical and chemical properties were characterized by XRD, SEM, FT-IR, TGA and other characterization. La-Zn(4,4'-dipy)(OAc) $)_{2}$ nanomaterial achieved effective adhesion on the tannin-modified bacterial cellulose membrane. Adsorption experiments showed that the composite membrane can both adsorb total phosphorus and ammonia nitrogen, and adsorption capacity of ammonia nitrogen is better than that of total phosphorus. The maximum adsorption capacities of ammonia nitrogen and total phosphorus are $482.35 \mathrm{mg} / \mathrm{g}$ and $374.71 \mathrm{mg} / \mathrm{g}$. In the binary solution, the adsorption capacity of the composite membrane to ammonia nitrogen and total phosphorus decreased, but the adsorption capacity to phosphorus decreased slightly. Results of adsorption experiments showed that the adsorption process of nitrogen and phosphorus by the composite membrane belongs to single-layer adsorption, and the calculation results of the kinetic equation are in accordance with the quasi-second-order, and the adsorption equilibrium of the composite membrane was reached within $360 \mathrm{~min}$. In short, the composite membrane has a better adsorption and separation effect both on ammonia nitrogen and total phosphorus.

Keywords

Phosphorus; Ammonia nitrogen; Adsorption; Bacterial cellulose; Membrane; Tannic acid 


\section{Introduction}

Water eutrophication, driven by rapid population growth has become a threat to human existence and thus regarded as one of most common environmental problems worldwide.(Copetti et al. 2016; Schindler 2012) Especially, China have suffered from eutrophication for decades.(Shi et al. 2019; Yan et al. 2019; Zhang et al. 2020a) Diffuse nitrogen and phosphorus pollutions are now regard as the main drivers of water eutrophication.(Li et al. 2019a; Taipale et al. 2019) So, reduce the content of total phosphorus (TP) and ammonia nitrogen in water is an effective way to control eutrophication. At present, there are mainly three practical repair methods: engineering repair, chemical repair, and biological repair. Engineering repair removes nutrients from the surface sediments in water by hydraulic or mechanical means.(Bormans et al. 2016) The effect of engineering repair is remarkable. However, harmful ingredients such as large amounts of nutrients and heavy metals may return to the water body and cause secondary pollution. The water diversion will reduce the environmental pressure that restricts the growth and reproduction of algae because of the dilution effect. So, when water diversion is taken, the algae will show a momentum of increasing growth. The biological repair is a long-term and effective measure to eliminate the endogenous pollution in the water body.(Zhang et al. 2019) The biological method has the advantages of low cost, sustainability, simple operation, convenient management, and significant purification effect. But long-time process makes it unusable for the treatment of sudden and acute water pollution. For soluble nutrients, chemical repair is 
often the simplest and fastest method. The traditional chemical repair adopts methods such as adding chemicals into the water to form an insoluble precipitate. However, the use of agents will harm non-target organisms in water seriously and easy to cause secondary water pollution. So, green chemical treatments have always been a hot topic in water research.(Qiu et al. 2019)

Membrane adsorption is a greener and simpler than traditional chemical treatment. There are many selective adsorption sites on the surface of the membrane through chemical modification or material combination. When the continuous medium flows through membranes, membranes can selectively adsorb and separate specific pollutants.(Zhao et al. 2017; Zhu et al. 2017) Selective groups are firmly fixed on the surface of membrane materials through chemical modification so that the possibility of secondary pollution is very low. In addition, the macro size of the membrane materials makes membranes are very conducive to the treatment and separation process after adsorption compared with current nano-adsorption materials.(Wang et al. 2020) So, Membrane adsorption process has a huge application prospect in the field of environmental governance. Chemical modification requires strict reaction conditions and cumbersome steps, resulting in a higher composition of modified membrane materials. Inspired by the natural adhesion of biological mussels, we use tannic acid (TA) to construct a biomimetic membrane adsorption material.

TA is a typical natural polyphenol compound with a large number of hydroxyl groups, which can interact with the biopolymer (for example, some proteins, digestive 
enzymes, carbohydrates and minerals, etc.) to provide more chemical properties for the tannic acid. TA can adhere to a variety of substrates, thanks to its surface catechol and catechol groups and a large number of hydroxyl groups. (Li et al. 2020) Ejima et al reported a green, simple and rapid coating method, in which $\mathrm{TA}$ and $\mathrm{Fe}^{3+}$ were used to synthesize metal organic coordination compounds on various substrates to assemble functional organic membranes step by step.(Ejima et al. 2013)

Previously mentioned, controlling TP and ammonia nitrogen in water is an effective way to govern eutrophication. As far as we know, there have been few reports on the selective control of these two substances simultaneously. We use bacterial cellulose (BC) as the membrane substrate due to its excellent pore structure and low cost. But adsorption capacity of bacterial cellulose membrane for TP and ammonia nitrogen is poor and non-selective. TA can be used as an excellent modifier and bond bridge connector. different materials can be simply bonded to the membrane surface to achieve selective adsorption of different substances. Moreover, TA can exhibit strong interactions through multiple hydrogen bonds and hydrophobic interactions.(Shi et al. 2020) TA modified membrane materials can not only provide excellent adsorption sites, but also provide better secondary reaction platform to optimize adsorption. So, we use TA modified bacterial cellulose to construct efficient membrane adsorbent materials. Through biomimetic bonding, lanthanum-modified metal organic frame ( $\mathrm{La}-\mathrm{Zn}\left(4,4^{\prime}-\right.$ dipy $\left.)(\mathrm{OAc})_{2}\right)$ is bonded to the membrane surface to construct a membrane adsorption material with selective double adsorption for phosphorus and ammonia nitrogen. 
106

\section{Experimental}

2.1 Instrumentations and materials

The surface morphology was characterized by Scanning electron microscope (SEM, SUPRA 55, Germany). The Fourier transform infrared (FT-IR) spectrum was studied by IS50 spectrophotometer (United States). The spectral recording range was 4000-500 $\mathrm{cm}^{-1}$. Thermogravimetric analysis (TGA) was performed on the material using a thermogravimetric analyzer (Q600-TGA/DSC, USA) under $\mathrm{N}_{2}$ atmosphere. The X-ray diffraction (XRD) pattern is collected on Rigaku D/max 2500VL diffractometer (Japan) in a Bragg-Brentano configuration with an Angle $2 \theta$ of 5 to $80^{\circ}$ to show the change in the crystal structure of the films.

$\mathrm{Zn}\left(\mathrm{OCOCH}_{3}\right)_{2} \cdot 2 \mathrm{H}_{2} \mathrm{O}, 4,4$ '-bipyridine, $\mathrm{La}\left(\mathrm{NO}_{3}\right)_{3}$ and acetonitrile were purchased from Aladdin (Shanghai, China), tannic acid, ammonia chloride, potassium dihydrogen phosphate and methanol were purchased from Sinopharm Group Chemical Reagent Co., Ltd. (Shanghai, China)

\subsection{Preparation of La-Zn (4,4'-dipy)(OAc) ${ }_{2}$}

A metal organic framework material with $\mathrm{Zn}^{2+}$ as the metal ion junction and 4,4'bipyridine as the organic ligand linking bridge was prepared, in which $\mathrm{Zn}^{2+}$ was provided by $\mathrm{Zn}\left(\mathrm{OCOCH}_{3}\right)_{2} \cdot 2 \mathrm{H}_{2} \mathrm{O}$ reagent. The $\mathrm{Zn}\left(\mathrm{OCOCH}_{3}\right)_{2} \cdot 2 \mathrm{H}_{2} \mathrm{O}$ and $4,4^{\prime}$ 'bipyridine with a millimolar ratio of $2: 1$ were placed in a mixed solution of methanol/water, in which the volumes of methanol and distilled water were both $5 \mathrm{~mL}$, and stirred for 15 min to make the mixture uniform. The solution was sealed in a teflon 
reactor, and the yellow needle-like crystals were obtained after reacting at $60{ }^{\circ} \mathrm{C}$ for 24 hours. After washing with methanol and drying in a vacuum oven, and noted as $\mathrm{Zn}$ (4,4'-dipy)(OAc) $)_{2}$. Weighing $50 \mathrm{mg}$ of $\mathrm{Zn}(4,4$ '-dipy $)(\mathrm{OAc})_{2}$ and $25 \mathrm{mg}$ of $\mathrm{La}\left(\mathrm{NO}_{3}\right)_{3}$, mixed with $10 \mathrm{~mL}$ of acetonitrile, and refluxed at $80{ }^{\circ} \mathrm{C}$ for 2 hours. Then it was centrifuged for $15 \mathrm{~min}$, washed with methanol multiple times, and dried at $100{ }^{\circ} \mathrm{C}$ for 1 hour.

2.3 Preparation of tannic acid modified BC membrane

$\mathrm{BC}$ membrane was immersed in a $5 \mathrm{mg} / \mathrm{mL}$ of tannic acid solution, and replace the tannic acid solution every 12 hours for a total of 6 times. The tannic acid modified BC membrane was washed with deionized water and ethanol and dried in vacuum at $60{ }^{\circ} \mathrm{C}$ for 12 hours.

2.4 Preparation of tannic acid modified La-Zn(4,4'-dipy)(OAc) $)_{2} / \mathrm{BC}$ composite membrane

According to the above method, the tannic acid modified La- $\mathrm{Zn}(4,4$ 'dipy)(OAc) $)_{2}$ BC composite membrane was prepared. First, the $\mathrm{BC}$ membrane was modified with tannic acid, then the $\mathrm{Zn}\left(\mathrm{OCOCH}_{3}\right)_{2} \cdot 2 \mathrm{H}_{2} \mathrm{O}$ and 4,4'-bipyridine were weighed, and mixed with methanol and water, and then the modified tannic acid BC membrane was placed in it and reacted together in a teflon reactor for 24 hours at room temperature. After washing and drying the obtained composite membrane with methanol for several times, the composite membrane was refluxed at $80^{\circ} \mathrm{C}$ for 2 hours in the mixed solution of $\mathrm{La}\left(\mathrm{NO}_{3}\right)_{3}$ and acetonitrile. After washing with methanol for 
several times, and dried. The preparation process is shown in Figure 1.

\subsection{Effect of $\mathrm{pH}$ on adsorption}

In this experiment, a binary mixed solution with $\mathrm{NH}_{4}{ }^{+}-\mathrm{N}$ and TP concentrations of $100 \mathrm{mg} / \mathrm{L}$ were prepared using $\mathrm{NH}_{4} \mathrm{Cl}$ and $\mathrm{KH}_{2} \mathrm{PO}_{4} \cdot \mathrm{H}_{2} \mathrm{SO}_{4}$ as an acid regulator, adjusting the $\mathrm{pH}$ of the mixed solution to 2.0, 4.0 and 6.0 , and $\mathrm{NaOH}$ was used to adjust the $\mathrm{pH}$ of solution to $7.0,8.0,10.0$ and 12.0 , take $10 \mathrm{~mL}$ of $\mathrm{pH}$-adjusted binary solution, add $10 \mathrm{mg}$ of tannin-modified La-Zn(4,4'-dipy)(OAc) $2 / \mathrm{BC}$ composite membrane, and shake at $25^{\circ} \mathrm{C}$ for 24 hour. The concentration of ammonia nitrogen and total phosphorus in water were measured by Nessler reagent colorimetry and ammonium molybdate spectrophotometry, respectively. Calculate the adsorption capacity $\left(\mathrm{Q}_{\mathrm{e}}\right)$ by formula (1):

$$
\mathrm{Q}_{\mathrm{e}}=\frac{\left(\mathrm{C}_{0}-\mathrm{C}_{\mathrm{e}}\right) \times \mathrm{V}}{\mathrm{W}}
$$

Among them, $\mathrm{C}_{0}(\mathrm{mg} / \mathrm{L})$ represents the initial concentration of the binary mixed solution; $\mathrm{C}_{\mathrm{e}}(\mathrm{mg} / \mathrm{L})$ represents the equilibrium concentration of the binary mixed solution; $\mathrm{V}(\mathrm{mL})$ is the volume of the binary mixture, and $\mathrm{W}(\mathrm{mg})$ is the mass of the adsorbent.

\subsection{Adsorption kinetics}

Taking the binary mixed solution with $\mathrm{NH}_{4}^{+}-\mathrm{N}$ and TP concentration of $350 \mathrm{mg} / \mathrm{L}$. Firstly, $\mathrm{pH}$ was adjusted to 7.0 , and then $10 \mathrm{~mL}$ of the solution was taken and $10 \mathrm{mg}$ of tannic acid modified La-Zn(4,4'-dipy) $(\mathrm{OAc})_{2} / \mathrm{BC}$ composite membrane was immersed in it. The concentrations of ammonia nitrogen and total phosphorus at 5, 10, 30, 60, 120, $180,240,360,420,540,600$ and 660 min were measured at $25^{\circ} \mathrm{C}$. 
2.7 Adsorption isotherm

A binary mixture of $\mathrm{NH}_{4}^{+}-\mathrm{N}$ and $\mathrm{TP}$ solution, $\mathrm{NH}_{4}^{+}-\mathrm{N}$ and $\mathrm{TP}$ solution were prepared with concentrations of 10, 50, 100, 150, 250, 350, 500, 800 and $1000 \mathrm{mg} / \mathrm{L}$, respectively. Then $10 \mathrm{mg}$ of tannin-modified $\mathrm{La}-\mathrm{Zn}(4,4$ '-dipy)(OAc) $2 / \mathrm{BC}$ composite membrane was added to the solution, and oscillation under $25{ }^{\circ} \mathrm{C}$ for 24 hours. The concentrations of ammonia nitrogen and total phosphorus in water were measured by nessler reagent colorimetry and ammonium molybdate spectrophotometry.

2.8 Dynamic adsorption

A binary mixed solution of $\mathrm{NH}_{4}^{+}-\mathrm{N}$ and $\mathrm{TP}$ with a concentration of $50 \mathrm{mg} / \mathrm{L}$ was prepared, and pass the water sample at a flow rate of $0.0062 \mathrm{~L} / \mathrm{min}$ through the composite membrane with a diameter of $3 \mathrm{~cm}$. The concentrations of ammonia nitrogen and total phosphorus in the solution were determined at an interval of 1 hour.

\section{Results and discussion}

\subsection{Characterization results and analysis}

The crystal structures of Zn(4,4'-dipy)(OAc) $)_{2}$ and La-Zn(4,4'-dipy)(OAc) $)_{2}$ can be determined by X-ray diffraction (XRD). As shown in Figure 2, Zn(4,4'-dipy)(OAc) 2 showed a higher peak intensity at $2 \theta=6^{\circ}$, where the peak intensity belongs to $\mathrm{Zn}^{2+}$, the peak strength of La- $\mathrm{Zn}(4,4$ '-dipy $)(\mathrm{OAc})_{2}$ after modification of lanthanum was significantly reduced at $2 \theta=6^{\circ}$, and a new characteristic peak appeared between $2 \theta=30^{\circ}-40^{\circ}$, all of which can account for the payload of lanthanum. This is consistent with the previous research results of our group work. (Wei et al. 2020a) 
surface show a three-dimensional network cross-linked structure (Figure 3a), which is the special structure of bacterial cellulose. Figure $3 b$ show the load of La-Zn $(4,4$ 'dipy $)(\mathrm{OAc})_{2}$ was observed on the membrane surface, which confirmed that $\mathrm{La}-\mathrm{Zn}\left(4,4^{\prime}-\right.$ dipy $)(\mathrm{OAc})_{2}$ and $\mathrm{BC}$ could be effectively prepared by tannic acid modified. It is also proved that the addition of $\mathrm{La}-\mathrm{Zn}\left(4,4^{\prime}-\mathrm{dipy}\right)(\mathrm{OAc})_{2}$ has no effect on the structure of BC.

The FT-IR chart can clearly understand the functional group properties of $\mathrm{Zn}(4,4$ 'dipy)(OAc) $)_{2}$ and La-Zn(4,4'-dipy)(OAc)2. As shown in Figure 4, a wide and strong characteristic peak of $-\mathrm{NH}_{2}$ appeared near $3430 \mathrm{~cm}^{-1}$, which is belong to the characteristic peak of an organic ligand named as 4,4'-bipyridine in the $\mathrm{Zn}\left(4,4^{\prime}\right.$ dipy $)(\mathrm{OAc})_{2}$ material. After the intercalation of the lanthanum, the peak strength of the material at $1360 \mathrm{~cm}^{-1}$ was enhanced, and the special vibration of nitrate anion appeared at $1560 \mathrm{~cm}^{-1}$, indicating the effective encapsulation of the element $\mathrm{La}$. La- $\mathrm{Zn}\left(4,4^{\prime}-\right.$ dipy $)(\mathrm{OAc})_{2} / \mathrm{BC}$ also showed the characteristic peaks near $1560 \mathrm{~cm}^{-1}$ and $1360 \mathrm{~cm}^{-1}$, indicating that $\mathrm{La}-\mathrm{Zn}\left(4,4^{\prime}\right.$-dipy $)(\mathrm{OAc})_{2}$ successfully combined with tannin-modified BC.

The TG/DTG of $\mathrm{Zn}\left(4,4^{\prime}\right.$ 'dipy $)(\mathrm{OAc})_{2}$ and $\mathrm{La}-\mathrm{Zn}\left(4,4^{\prime} \text {-dipy)(OAc) }\right)_{2}$ are shown in Figure 5. It can be seen in the figure that when lanthanum is intercalated in the MOFs material, its mass loss is $20 \%$ higher than that of $\mathrm{Zn}\left(4,4^{\prime}\right.$-dipy $)(\mathrm{OAc})_{2}$. The doping of lanthanum element increased the thermal stability of the MOFs. Figure 5(a) showed 
that the decomposition of the MOFs material can be divided into three stages. The first stage is that when the temperature increases to $100^{\circ} \mathrm{C}, \mathrm{Zn}\left(4,4^{\prime}-\right.$ dipy $)(\mathrm{OAc})_{2}$ began to decompose, at this time the mass is reduced by about $6 \%$. The second stage is at 112 $187^{\circ} \mathrm{C}$, the mass is reduced by about $16 \%$, and final stage is at $187-302{ }^{\circ} \mathrm{C}$, its decomposition rate is significantly lower than the former two stages, the mass has lost about $14 \%$. It can be seen from Figure 5(b) that the decomposition process of La$\mathrm{Zn}\left(4,4^{\prime}\right.$-dipy $)(\mathrm{OAc})_{2}$ at a heating rate of $10{ }^{\circ} \mathrm{C} / \mathrm{min}$ is also divided into three stages, namely $48-155^{\circ} \mathrm{C}, 155-237^{\circ} \mathrm{C}$ and $237-508^{\circ} \mathrm{C}$, with corresponding mass loss of $6 \%$, $11 \%$ and $7 \%$.

\subsection{Effect of $\mathrm{pH}$ on adsorption}

The effects of different $\mathrm{pH}$ values on the adsorption of ammonia nitrogen and total phosphorus by the composite membrane were compared. As shown in Figure 6, when the $\mathrm{pH}$ value of the binary mixed solution is acidic, the adsorption capacity of the composite membrane material for $\mathrm{NH}_{4}^{+}-\mathrm{N}$ in the water should be less than $10 \mathrm{mg} / \mathrm{g}$, which is because the ammonia nitrogen in the water is mainly in form of $\mathrm{NH}_{4}^{+}$, and the low $\mathrm{pH}$ conditions are not conducive to the adsorption. However, under acidic $\mathrm{pH}$ conditions, the adsorption capacity of the composite membrane for total phosphorus is much higher than that of ammonia nitrogen in the water. With the increase of $\mathrm{pH}$ value to 7.0 , the adsorption capacity of tannic acid modified La-Zn(4,4'-dipy)(OAc) $2 / \mathrm{BC}$ composite membrane to $\mathrm{NH}_{4}^{+}-\mathrm{N}$ and TP in the water reached the highest. The $\mathrm{pH}$ of the solution was adjusted to alkaline, with the increase of $\mathrm{OH}^{-}$, the competitive adsorption 
between $\mathrm{OH}^{-}$and $\mathrm{PO}_{4}^{3-}$ leads to a decrease in the adsorption capacity of the composite membrane to the TP in the binary mixed solution. At this point, the $\mathrm{NH}_{4}^{+}$in the solution rapidly decreases, most of the molecular forms in the water are mainly $\mathrm{NH}_{3}$, which is not conducive to the adsorption of ammonia nitrogen in the composite membrane. Based on the above trends, the following adsorption experiment was conducted at $\mathrm{pH}$ $=7.0$.

\subsection{Adsorption dynamics}

$\mathrm{Q}_{t}$ is given by formula (2):(Zhang et al. 2020b)

$$
\mathrm{Q}_{\mathrm{t}}=\frac{\left(\mathrm{C}_{0}-\mathrm{C}_{\mathrm{t}}\right) \times \mathrm{V}}{\mathrm{W}}
$$

Among them, $Q_{t}(\mathrm{mg} / \mathrm{g})$ represents the adsorption amount of ammonia nitrogen and total phosphorus at time $\mathrm{t}$, while $\mathrm{C}_{\mathrm{t}}(\mathrm{mg} / \mathrm{L})$ represents the adsorption equilibrium concentration at time $\mathrm{t}$.

Figure 7 showed the kinetics fitting model of tannic acid modified La-Zn(4,4'dipy $)(\mathrm{OAc})_{2} / \mathrm{BC}$ composite membrane adsorption ammonia nitrogen and total phosphorus, within the first 120 min the adsorption capacity of $\mathrm{NH}_{4}^{+}-\mathrm{N}$ and $\mathrm{TP}$ in the composite membrane rapidly increased to $133.83 \mathrm{mg} / \mathrm{g}$ and $126.08 \mathrm{mg} / \mathrm{g}$. From $120 \mathrm{~min}$ to $360 \mathrm{~min}$, the adsorption capacity of $\mathrm{NH}_{4}^{+}-\mathrm{N}$ and $\mathrm{TP}$ by the composite membrane increased gradually, The adsorption process reached adsorption equilibrium at $360 \mathrm{~min}$, and the adsorption capacity of the $\mathrm{La}-\mathrm{Zn}\left(4,4^{\prime}-\mathrm{dipy}\right)(\mathrm{OAc})_{2} / \mathrm{BC}$ composite membrane gradually saturated. Figure 7 showed that at the beginning of adsorption, the adsorption capacity of $\mathrm{NH}_{4}^{+}-\mathrm{N}$ and TP is almost the same. With the increase of adsorption time, the 
adsorption capacity of the adsorbent for $\mathrm{NH}_{4}^{+}-\mathrm{N}$ in the water is higher than its adsorption capacity for the TP. The adsorption data were fitted into quasi-first-order kinetic equations (3) and quasi-second-order kinetic equations (4).(Meng et al. 2019)

$$
\begin{aligned}
& \ln \left(Q_{\mathrm{e}}-\mathrm{Q}_{\mathrm{t}}\right)=\ln \mathrm{Q}_{\mathrm{e}}-\mathrm{k}_{1} \mathrm{t} \\
& 1 /\left(\mathrm{Q}_{\mathrm{e}}-\mathrm{Q}_{\mathrm{t}}\right)=1 / \mathrm{Q}_{\mathrm{e}}+\mathrm{k}_{2} \mathrm{t}
\end{aligned}
$$

Where, $\mathrm{k}_{1}$ and $\mathrm{k}_{2}$ respectively represent the adsorption rate constants of tannic acid modified $\mathrm{La}-\mathrm{Zn}\left(4,4^{\prime}\right.$-dipy $)(\mathrm{OAc})_{2} / \mathrm{BC}$ composite membrane. In addition, the formula (5) is the initial adsorption rate $\mathrm{h}(\mathrm{mg} /(\mathrm{g} \bullet \mathrm{min}))$ of the material, and the half equilibrium time $t_{1 / 2}(\mathrm{~min})$ can be calculated by formula (6).(Li et al. 2019b)

$$
\begin{aligned}
& \mathrm{h}=\mathrm{k}_{2} \mathrm{Q}_{\mathrm{e}}^{2} \\
& \mathrm{t}_{1 / 2}=1 / \mathrm{k}_{2} \mathrm{Q}_{\mathrm{e}}
\end{aligned}
$$

According to the data in Table 1, the first order kinetic model was used to fit the adsorption process, and it was found that the coefficient of determination values $\left(\mathrm{R}^{2}\right)$ of the composite membrane adsorption were 0.97844 and 0.97604 , less than the values of $\mathrm{R}^{2}$ of the second order kinetic equation were 0.99097 and 0.98992 . The adsorption process of the composite membrane was in accordance with quasi second order kinetic equation. The adsorption capacities of the $\mathrm{NH}_{4}^{+}-\mathrm{N}$ and $\mathrm{TP}$ calculated by the formula was $193.52 \mathrm{mg} / \mathrm{g}$ and $162.58 \mathrm{mg} / \mathrm{g}$, respectively. The adsorption rate constants of the composite membrane are $0.00010242 \mathrm{~g} / \mathrm{mg} / \mathrm{min}$ and $0.00018993 \mathrm{~g} / \mathrm{mg} / \mathrm{min}$, respectively. The fitting results prove that the adsorption process is mainly chemical adsorption. 


\subsection{Adsorption isotherm}

The adsorption effect of tannic acid modified La-Zn(4,4'-dipy)(OAc) $2 / \mathrm{BC}$ composite membrane on ammonia nitrogen and total phosphorus in binary mixed solution was studied by static adsorption experiment. Use the following equations (7) and (8) to fit the data to the Langmuir and Freundlich equations:(Xu et al. 2018; Zheng et al. 2019; Zheng et al. 2020; Zhuo et al. 2018)

$$
\begin{aligned}
& Q_{e}=\frac{K_{L} Q_{m} C_{e}}{1+K_{L} C_{e}} \\
& Q_{e}=K_{F} C_{e}^{1 / n}
\end{aligned}
$$

$\mathrm{Q}_{\mathrm{m}}(\mathrm{mg} / \mathrm{L})$ in formula (7) represents the maximum adsorbent adsorption capacity, while $\mathrm{K}_{\mathrm{L}}(\mathrm{L} / \mathrm{mg})$ refers to Langmuir binding constant, which depends on temperature and adsorption heat. In formula (8), 1/n represents the Freundlich constant, which depends on the adsorption system. $K_{F}(\mathrm{mg} / \mathrm{g})$ is a constant, depending on the characteristics and quantity of the adsorbed material.

The advantages of adsorption can be determined by calculating the separation factor $\mathrm{R}_{\mathrm{L}}$, whose formula is as follows(9):(Basnett et al. 2012; Xu et al. 2020; Zhang et al. 2020b)

$$
\mathrm{R}_{\mathrm{L}}=\frac{1}{1+\mathrm{C}_{\mathrm{m}} \mathrm{K}_{\mathrm{L}}}
$$

Figure 8 compares the adsorption capacity of tannic acid modified La-Zn(4,4'dipy)(OAc) $)_{2} / \mathrm{BC}$ composite membrane to ammonia nitrogen and total phosphorus.

Figure 8 shows that the adsorption effect of tannic acid modified La-Zn(4,4'dipy)(OAc) $)_{2} / \mathrm{BC}$ composite membrane on ammonia nitrogen is better than that on total 
phosphorus. According to the data in Table 2, the saturated adsorption capacity of $\mathrm{NH}_{4}{ }^{+}-$

$\mathrm{N}$ in the binary mixed solution is $466.33 \mathrm{mg} / \mathrm{g}$, while the saturated adsorption capacity $\mathrm{Q}_{\mathrm{m}}$ of single-component $\mathrm{NH}_{4}{ }^{+}-\mathrm{N}$ is $482.35 \mathrm{mg} / \mathrm{g}$. The saturated adsorption capacity of total phosphorus in the binary mixed solution was $370.94 \mathrm{mg} / \mathrm{g}$, while the saturated adsorption capacity of single component total phosphorus was $374.71 \mathrm{mg} / \mathrm{g}$, which also showed a decrease in adsorption capacity, but with a small decrease. Our previous studies have found that La-modified MOFs has a selective adsorption and separation effect on total phosphorus(Wei et al. 2020b), but tannic acid has no selective adsorption effect on both total phosphorus and ammonia nitrogen, which can explain why the effect of the tannic acid modified $\mathrm{La}-\mathrm{Zn}\left(4,4^{\prime}\right.$ '-dipy $)(\mathrm{OAc})_{2} / \mathrm{BC}$ composite membrane on phosphorus decreased less than that of ammonia nitrogen.

According to the fitting data of the Langmuir and Freundlich equations in Table 2 and Table 3, Langmuir fitting equation $\mathrm{R}^{2}$ is greater than the Freundlich fitting equation. Therefore, it can be proved that the adsorption of ammonia nitrogen and total phosphorus by tannic acid modified La-Zn(4,4'-dipy)(OAc) $2 / \mathrm{BC}$ composite membrane is more likely to conform to the Langmuir equation, indicating that it is a monolayer adsorption process. In addition, $\mathrm{R}_{\mathrm{L}}$ is greater than 0 and less than 1 , indicating that the adsorption process of $\mathrm{NH}_{4}^{+}-\mathrm{N}$ and $\mathrm{TP}$ by the composite membrane was the preferred adsorption process.

\subsection{Dynamic adsorption}

Dynamic adsorption experiments were carried out on the binary mixed solution of 
ammonia nitrogen and total phosphorus. Figure 9 showed the penetration curves of ammonia nitrogen and total phosphorus in the mixed solution adsorbed by the composite membrane. Penetration curve is generally an S-shaped curve, and the inclination of the S-shaped curve is different under different circumstances. The penetration point can only be accurately obtained through experiments. Take the point in the figure where the adsorption capacity rises sharply as the penetration point. The adsorption of $\mathrm{NH}_{4}^{+}-\mathrm{N}$ and TP by the tannic acid modified $\mathrm{La}-\mathrm{Zn}\left(4,4^{\prime}-\mathrm{dipy}\right)(\mathrm{OAc})_{2} / \mathrm{BC}$ composite membrane showed a penetration point between 60 and $120 \mathrm{~min}$. The end point of the penetration curve was taken as the inflexion point at the top of the S-shaped curve close to the initial concentration. Therefore, the penetration curve reached the end point at $480 \mathrm{~min}$, and the penetration time of the composite membrane for $\mathrm{NH}_{4}^{+}-\mathrm{N}$ and TP in the water was 8 hours at the initial concentration of $50 \mathrm{mg} / \mathrm{L}$ and a flow rate of $0.0062 \mathrm{~L} / \mathrm{min}$.

\subsection{Reusability tests}

The amount of adsorbent used greatly affects the cost of treating sewage, so it is very important to improve the reusability of adsorbent and minimize the amount of adsorbent required. The adsorbed tannin-modified $\mathrm{La}-\mathrm{Zn}\left(4,4^{\prime}-\mathrm{dipy}\right)(\mathrm{OAc})_{2} / \mathrm{BC}$ composite membrane was transferred to the eluent ( $10 \%$ glacial acetic acid) for 48 hours and rinsed with ultra-pure water for three times before drying. The whole adsorption desorption process was repeated 5 times. As can be seen from Figure 10, after 5 cycles, the adsorption capacity of ammonia nitrogen of the composite membrane 
decreased to $80.94 \%$, and the adsorption capacity of total phosphorus decreased to $82.91 \%$, which we believe was mainly caused by eluting the imprinted binding site. Although the adsorption capacity of the composite membrane decreased after 5 cycles, it still remained above $80 \%$ with good reusability and could be used as a reliable adsorbent for the separation of ammonia nitrogen and total phosphorus in water.

\section{Conclusions}

In this experiment, the tannic acid modified $\mathrm{La}-\mathrm{Zn}\left(4,4^{\prime}\right.$-dipy $)(\mathrm{OAc})_{2} / \mathrm{BC}$ composite membrane was prepared for adsorption of total phosphorus and ammonia nitrogen. When the $\mathrm{pH}$ is 7.0 , the adsorption capacity of the composite membrane material to the binary mixed solution of ammonia nitrogen and total phosphorus in water were $466.33 \mathrm{mg} / \mathrm{g}$ and $370.94 \mathrm{mg} / \mathrm{g}$. The data fitting of total phosphorus and ammonia nitrogen in the water adsorbed by the tannic acid modified La- $\mathrm{Zn}\left(4,4^{\prime}-\right.$ dipy $)(\mathrm{OAc})_{2} / \mathrm{BC}$ composite membrane conformed to the Langmuir equation and the quasi second order kinetic equation, which showed that the adsorption reaction belongs to monolayer chemical adsorption. The equilibrium between the $\mathrm{La}-\mathrm{Zn}\left(4,4^{\prime}\right.$ dipy $)(\mathrm{OAc})_{2} / \mathrm{BC}$ composite membrane and the water sample can be obtained by the dynamic adsorption breakthrough curve. All these results indicate the tannic acid modified La- $\mathrm{Zn}\left(4,4^{\prime}\right.$-dipy $)(\mathrm{OAc})_{2} / \mathrm{BC}$ composite membrane has good adsorption properties for ammonia nitrogen and total phosphorus, and can effectively adsorb pollutants in water.

\section{Declarations}


5.1 Ethics approval and consent to participate Not applicable.

5.2 Consent for publication

Not applicable.

5.3 Availability of data and materials

All data generated or analysed during this study are included in this published article.

\subsection{Competing interests}

The authors declare that they have no competing interests" in this section.

\subsection{Acknowledgements}

The authors thank the National Natural Science Foundation of China (Grant Nos. 21876015, 21808018), Applied Basic Research of Changzhou (Grant No. CJ20180055), Natural Science Research of Jiangsu Higher Education Institutions of China (Grant No. 18KJB610002), Science and Technology Support Program of Changzhou (Grant No. CE20185015). The authors are grateful to Wang Liang from Shiyanjia Laboratory for providing us with XPS analysis.

\subsection{Authors' contributions}

ZXD was the main contributor to the manuscript, and SW was used to analyze and interpret the data of material properties. WN, LLL, BTT and ZY were used to prepare the composite membrane, while ZYZ, LZY, and OHX proofread and checked the article. All the authors have seen the manuscript and approved to submit to your journal. 


\section{References}

Basnett P, Knowles JC, Pishbin F, Smith C, Keshavarz T, Boccaccini AR, Roy I (2012) Novel Biodegradable and Biocompatible Poly(3-hydroxyoctanoate)/Bacterial Cellulose Composites Advanced Engineering Materials 14:B330-B343 doi:10.1002/adem.201180076

Bormans M, Maršálek B, Jančula D (2016) Controlling internal phosphorus loading in lakes by physical methods to reduce cyanobacterial blooms: a review Aquat Ecol 50:407-422 doi:10.1007/s10452-015-9564-х

Copetti D et al. (2016) Eutrophication management in surface waters using lanthanum modified bentonite: A review Water Res 97:162-174 doi:10.1016/j.watres.2015.11.056

Ejima H et al. (2013) One-Step Assembly of Coordination Complexes for Versatile Film and Particle Engineering Science (New York, NY) 341:154-157 doi:10.1126/science. 1237265

Li A, Strokal M, Bai Z, Kroeze C, Ma L (2019a) How to avoid coastal eutrophication a back-casting study for the North China Plain Sci Total Environ 692:676-690 doi:https://doi.org/10.1016/j.scitotenv.2019.07.306

Li Q et al. (2020) Tannic acid assisted interfacial polymerization based loose thin-film composite NF membrane for dye/salt separation Desalination 479:114343

Li S et al. (2019b) Graphene oxide based dopamine mussel-like cross-linked polyethylene imine nanocomposite coating with enhanced hexavalent uranium 
adsorption Journal of Materials Chemistry A 7:16902-16911 doi:10.1039/c9ta04562g

Meng K et al. (2019) Efficient Adsorption of the Cd(II) and As(V) Using Novel Adsorbent Ferrihydrite/Manganese Dioxide Composites ACS Omega 4:1862718636 doi:10.1021/acsomega.9b02431

Qiu H, Ye M, Zeng Q, Li W, Fortner J, Liu L, Yang L (2019) Fabrication of agricultural waste supported UiO-66 nanoparticles with high utilization in phosphate removal from water Chem Eng J 360:621-630 doi:https://doi.org/10.1016/j.cej.2018.12.017

Schindler DW (2012) The dilemma of controlling cultural eutrophication of lakes Proc R Soc B 279:4322-4333 doi:10.1098/rspb.2012.1032

Shi K, Zhang Y, Zhang Y, Li N, Qin B, Zhu G, Zhou Y (2019) Phenology of Phytoplankton Blooms in a Trophic Lake Observed from Long-Term MODIS Data Environ Sci Technol 53:2324-2331 doi:10.1021/acs.est.8b06887

Shi M et al. (2020) Combining tannic acid-modified support and a green co-solvent for high performance reverse osmosis membranes J Membr Sci 595:117474

Taipale SJ, Vuorio K, Aalto SL, Peltomaa E, Tiirola M (2019) Eutrophication reduces the nutritional value of phytoplankton in boreal lakes Environ Res 179:108836 doi:https://doi.org/10.1016/j.envres.2019.108836

Wang J, Cahyadi A, Wu B, Pee W, Fane AG, Chew JW (2020) The roles of particles in enhancing membrane filtration: A review J Membr Sci 595:117570 
Wei N, Zheng X, Li Q, Gong C, Ou H, Li Z (2020a) Construction of lanthanum modified MOFs graphene oxide composite membrane for high selective phosphorus recovery and water purification J Colloid Interface Sci 565:337-344 doi:https://doi.org/10.1016/j.jcis.2020.01.031

Wei N, Zheng X, Li Q, Gong C, Ou H, Li Z (2020b) Construction of lanthanum modified MOFs graphene oxide composite membrane for high selective phosphorus recovery and water purification J Colloid Interface Sci 565:337-344 doi:10.1016/j.jcis.2020.01.031

Xu X et al. (2020) Film-like bacterial cellulose based molecularly imprinted materials for highly efficient recognition and adsorption of cresol isomers Chem Eng J 382 doi:10.1016/j.cej.2019.123007

Xu Y-T, Dai Y, Nguyen T-D, Hamad WY, MacLachlan MJ (2018) Aerogel materials with periodic structures imprinted with cellulose nanocrystals Nanoscale 10:3805-3812 doi:10.1039/c7nr07719j

Yan K et al. (2019) Phosphorus mitigation remains critical in water protection: A review and meta-analysis from one of China's most eutrophicated lakes Sci Total Environ 689:1336-1347 doi:10.1016/j.scitotenv.2019.06.302

Zhang J, Wang C, Jiang X, Song Z, Xie Z (2020a) Effects of human-induced eutrophication on macroinvertebrate spatiotemporal dynamics in Lake Dianchi, a large shallow plateau lake in China Environ Sci Pollut Res 27:13066-13080 doi:10.1007/s11356-020-07773-w 
Zhang X, Li B, Xu H, Wells M, Tefsen B, Qin B (2019) Effect of micronutrients on algae in different regions of Taihu, a large, spatially diverse, hypereutrophic lake Water Res 151:500-514

Zhang Y, Zheng X, Bian T, Zhang Y, Mei J, Li Z (2020b) PhosphorylatedCNC/MWCNT thin films-toward efficient adsorption of rare earth $\mathrm{La}$ (III) Cellulose 27:3379-3390 doi:10.1007/s10570-020-03012-0

Zhao R, Li X, Sun B, Li Y, Li Y, Yang R, Wang C (2017) Branched polyethylenimine grafted electrospun polyacrylonitrile fiber membrane: a novel and effective adsorbent for $\mathrm{Cr}(\mathrm{VI})$ remediation in wastewater J Mater Chem 5:1133-1144

Zheng X, Zhang Y, Bian T, Wang D, Li Z (2019) One-step fabrication of imprinted mesoporous cellulose nanocrystals films for selective separation and recovery of Nd(III) Cellulose 26:5571-5582 doi:10.1007/s10570-019-02482-1

Zheng XD, Zhang Y, Bian TT, Zhang YZ, Li ZY, Pan JM (2020) Oxidized carbon materials cooperative construct ionic imprinted cellulose nanocrystals films for efficient adsorption of Dy(III) Chem Eng J 381:10 doi:10.1016/j.cej.2019.122669

Zhu Z et al. (2017) Ultrahigh adsorption capacity of anionic dyes with sharp selectivity through the cationic charged hybrid nanofibrous membranes Chem Eng J $313: 957-966$

Zhuo H et al. (2018) A Supercompressible, Elastic, and Bendable Carbon Aerogel with Ultrasensitive Detection Limits for Compression Strain, Pressure, and Bending 


\section{Table and Figure Captions}

Table 1 Kinetic fitting results of composite membrane adsorbing binary component solution in water

Table 2 Single-component adsorption Langmuir and Freundlich equation fitting results Table 3 Fitting results of Langmuir and Freundlich equation for binary component adsorption

Figure 1 Synthesis of tannic acid modified $\mathrm{La} \mathrm{Zn}\left(4,4^{\prime} \text {-dipy)(OAc) }\right)_{2} / \mathrm{BC}$ composite membrane

Figure 2 XRD patterns of Zn(4,4'-dipy)(OAc) $)_{2}$ and $\mathrm{La}-\mathrm{Zn}\left(4,4^{\prime}\right.$-dipy $)(\mathrm{OAc})_{2}$

Figure 3 SEM images of two films: (a) BC, (b) La-Zn(4,4'-dipy)(OAc) $)_{2} / \mathrm{BC}$

Figure 4 FT-IR comparison of BC, $\mathrm{Zn}\left(4,4^{\prime}\right.$ '-dipy $)(\mathrm{OAc})_{2}$, La-Zn(4,4'-dipy)(OAc) $)_{2}$ and $\mathrm{La}-\mathrm{Zn}\left(4,4^{\prime}\right.$-dipy $)(\mathrm{OAc})_{2} / \mathrm{BC}$

Figure 5 TG/DTG diagram of $\mathrm{Zn}\left(4,4^{\prime} \text { '-dipy)(OAc) }\right)_{2}$ and $\mathrm{La}-\mathrm{Zn}\left(4,4^{\prime} \text {-dipy)(OAc) }\right)_{2}$ (a is $\mathrm{Zn}\left(4,4^{\prime} \text {-dipy)(OAc) }\right)_{2}$ TG/DTG diagram; b is La-Zn(4,4'-dipy)(OAc) 2 TG/DTG diagram)

Figure 6 Effect of $\mathrm{pH}$ on the adsorption of binary mixed solution of ammonia nitrogen and total phosphorus by the composite membrane

Figure 7 Comparison of kinetic adsorption of ammonia nitrogen and total phosphorus in binary mixed solution

Figure 8 Adsorption isotherm of ammonia nitrogen and total phosphorus (a is singlecomponent adsorption, $\mathrm{b}$ is the competitive adsorption) 
Figure 9 Dynamic adsorption comparisons of ammonia nitrogen and total phosphorus 486 in binary mixed solution ( $\mathrm{a}$ is the penetration curve of ammonia nitrogen adsorption, $\mathrm{b}$ 487 is the penetration curve of total phosphorus adsorption)

488 Figure 10 Adsorption capacity of composite membrane over 5 cycles 
Figures

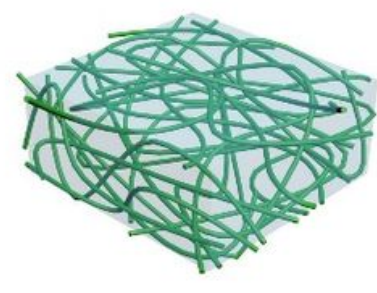

Bacterial cellulose (BC) membrane
Tannic acid

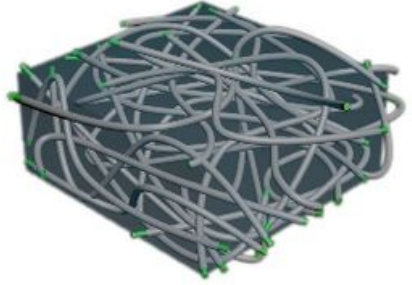

Tannic acid modified BC membrane
:La-Ln(4,4-dipy)(OA

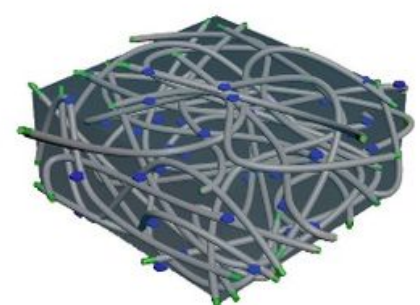

Tannic acid modified La-Zn( $4,4^{\prime}$-dipy $)(\mathrm{OAc}) / \mathrm{BC}$ composite membrane

Figure 1

Synthesis of tannic acid modified La Zn(4,4'-dipy)(OAc)2/BC composite membrane

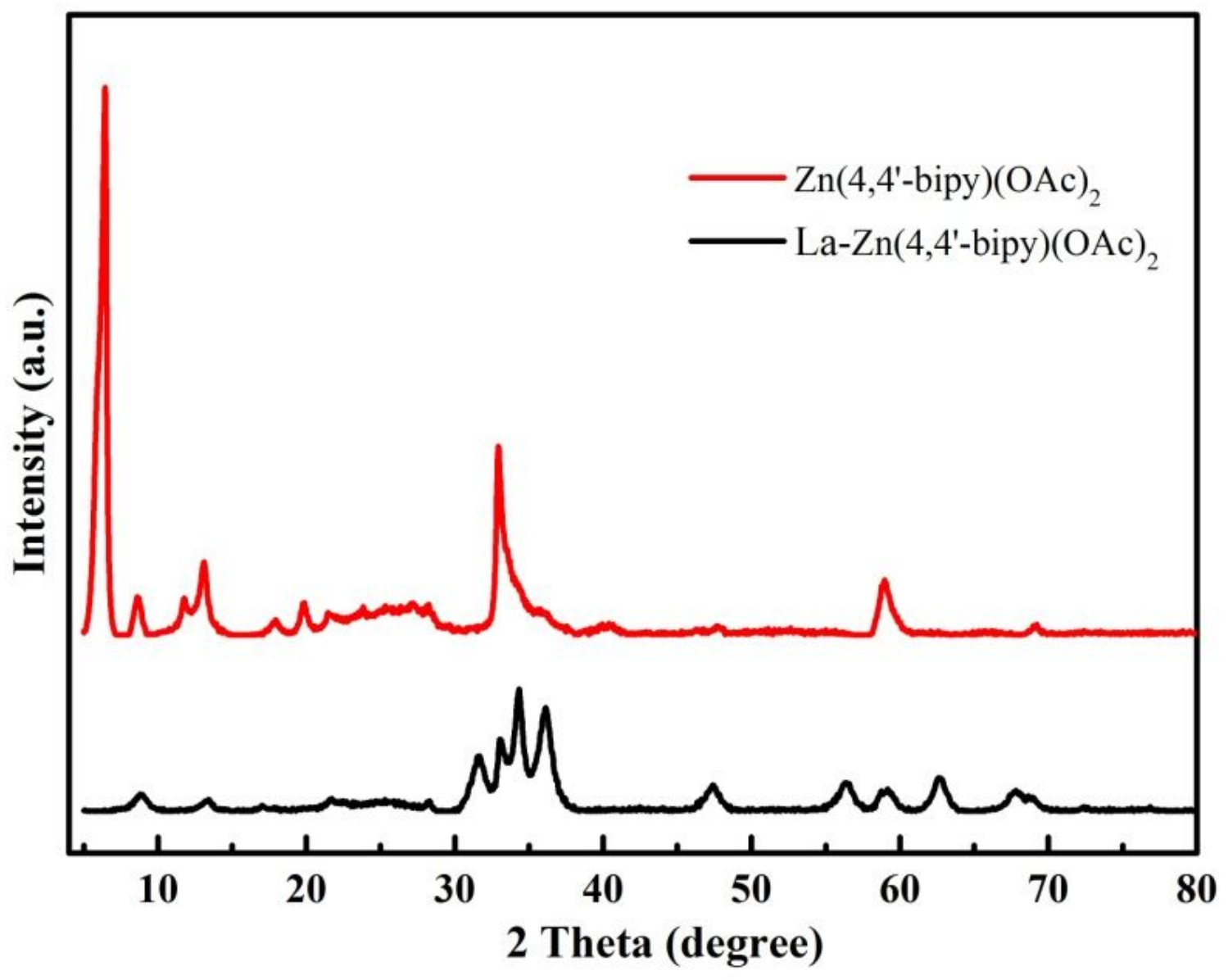

Figure 2 
XRD patterns of Zn(4,4'-dipy)(OAc)2 and La-Zn(4,4'-dipy)(OAc)2

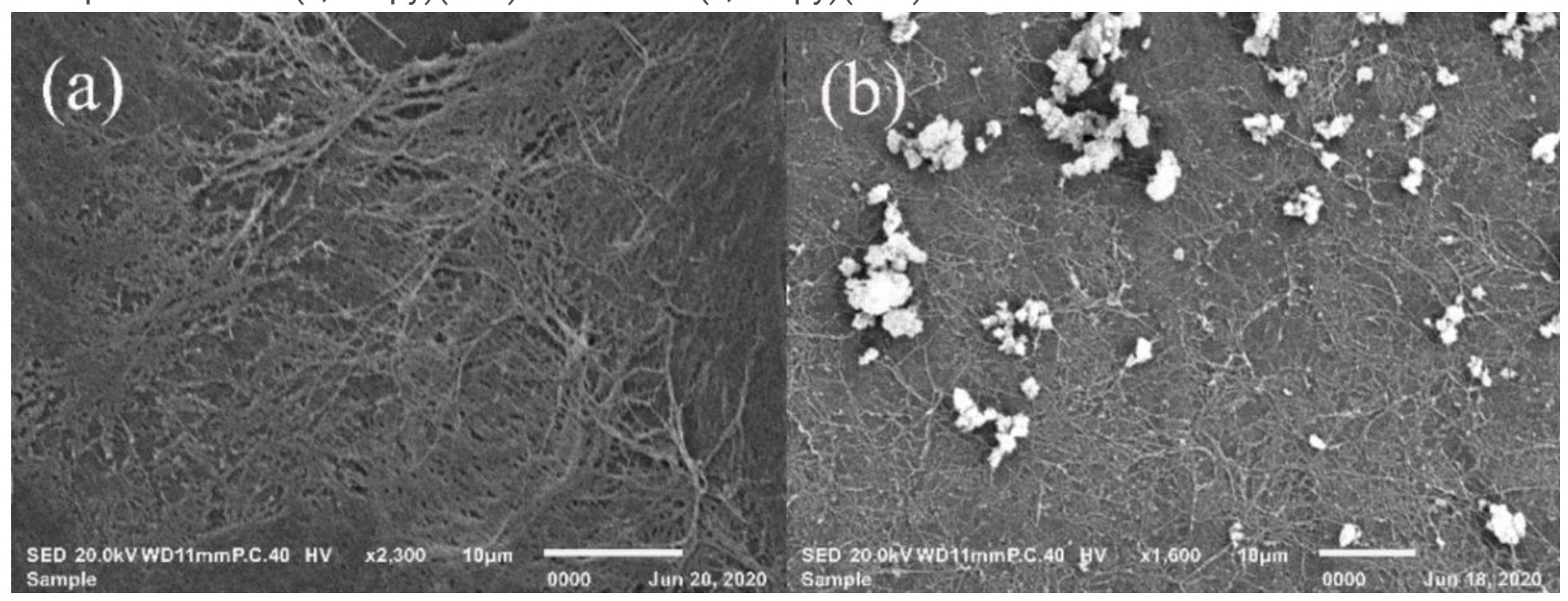

Figure 3

SEM images of two films: (a) BC, (b) La-Zn(4,4'-dipy)(OAc)2/BC

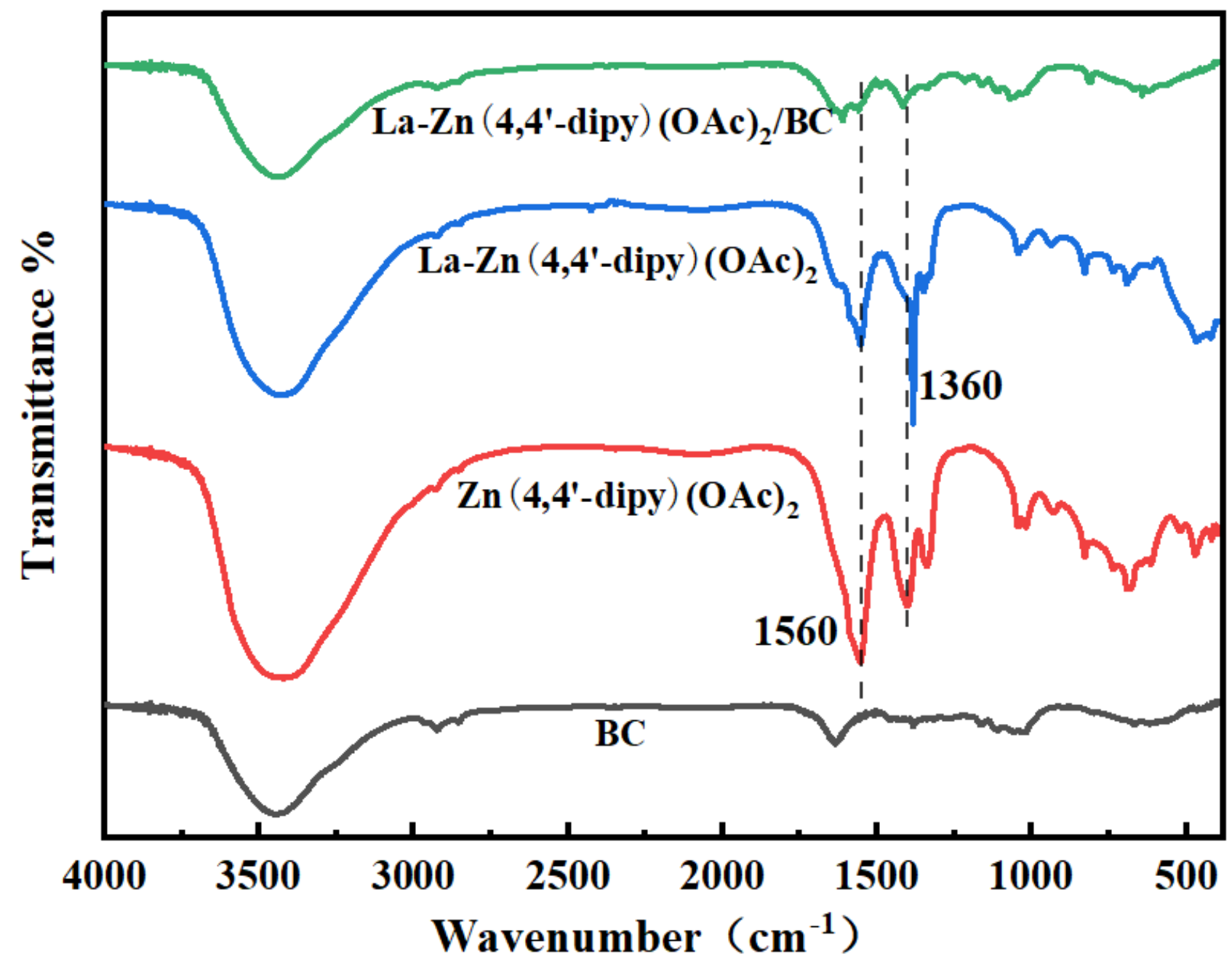


Figure 4

FT-IR comparison of BC, Zn(4,4'-dipy)(OAc)2, La-Zn(4,4'-dipy)(OAc)2 and La-Zn(4,4'-dipy)(OAc)2/BC
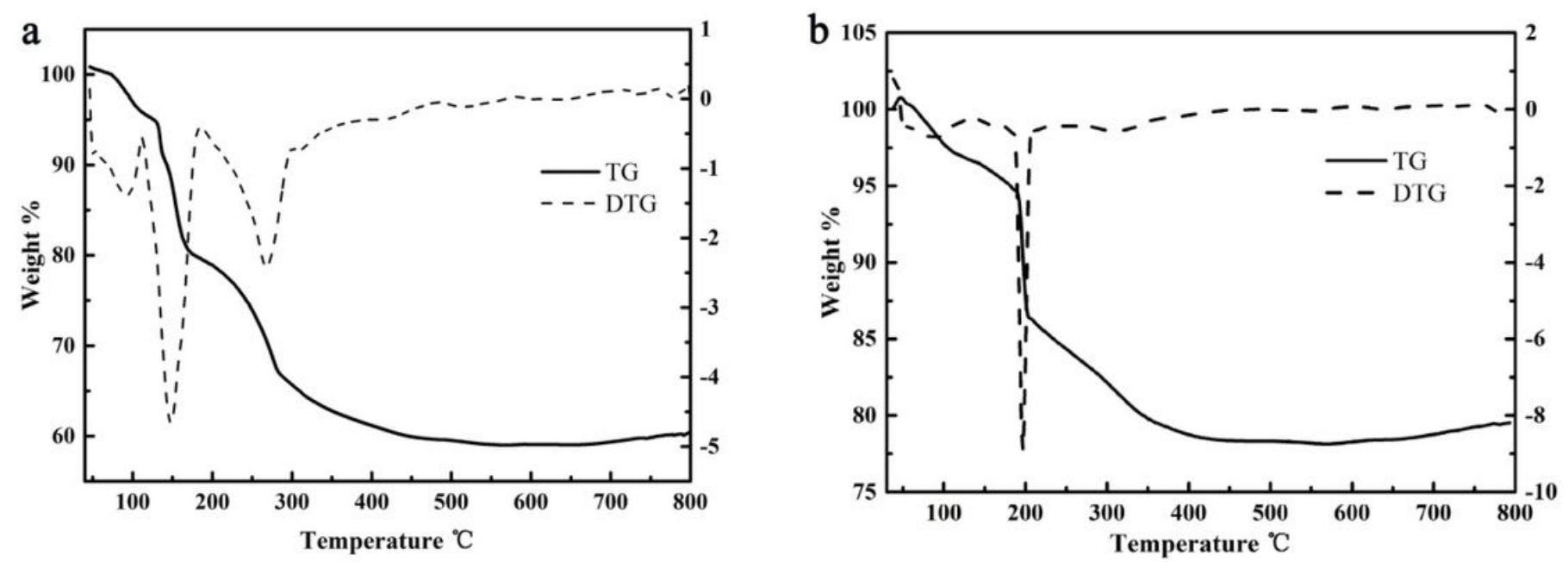

Figure 5

TG/DTG diagram of Zn(4,4'-dipy)(OAc)2 and La-Zn(4,4'-dipy)(OAc)2 (a is Zn(4,4'-dipy)(OAc)2 TG/DTG diagram; $b$ is La-Zn(4,4'-dipy)(OAc)2 TG/DTG diagram)

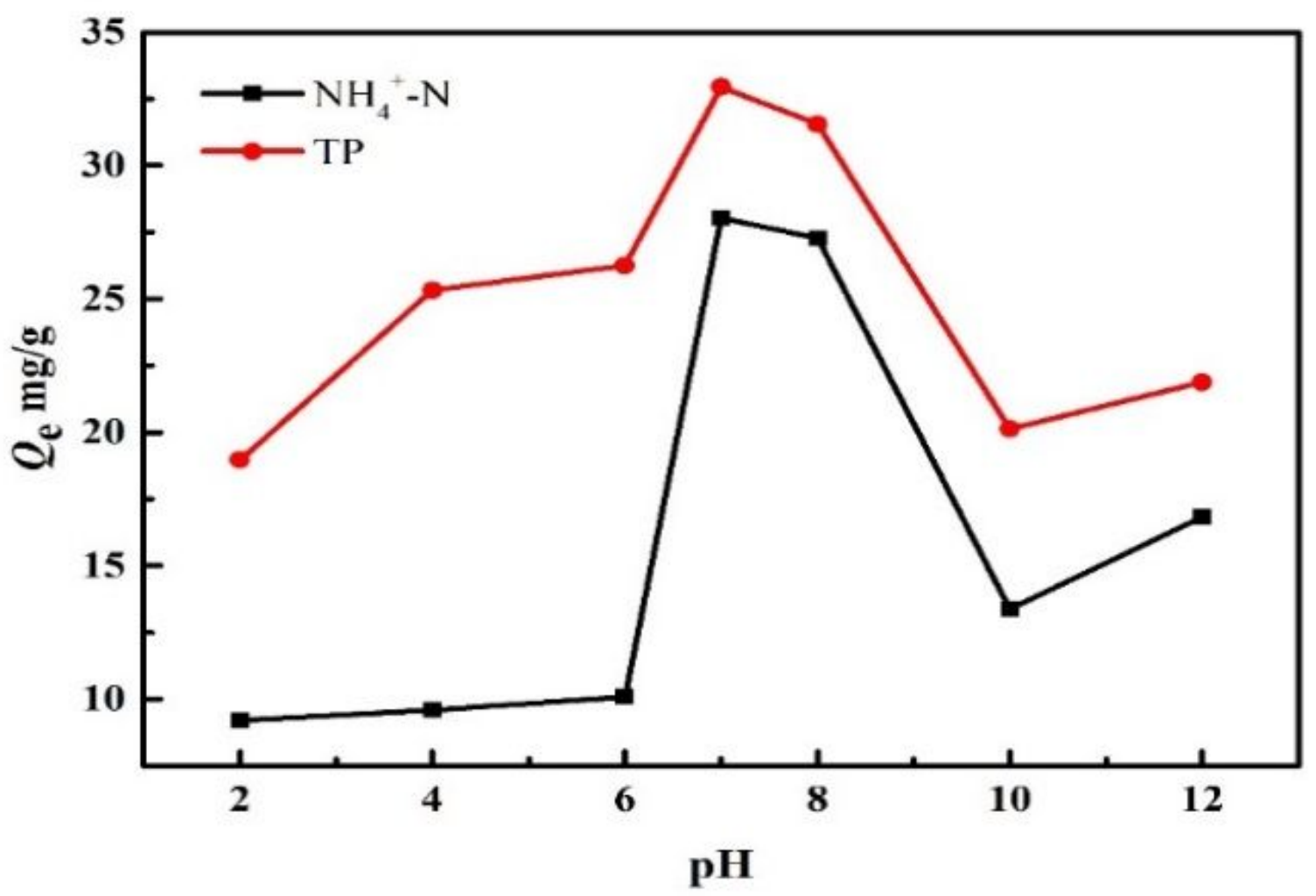

Figure 6 
Effect of $\mathrm{pH}$ on the adsorption of binary mixed solution of ammonia nitrogen and total phosphorus by the composite membrane

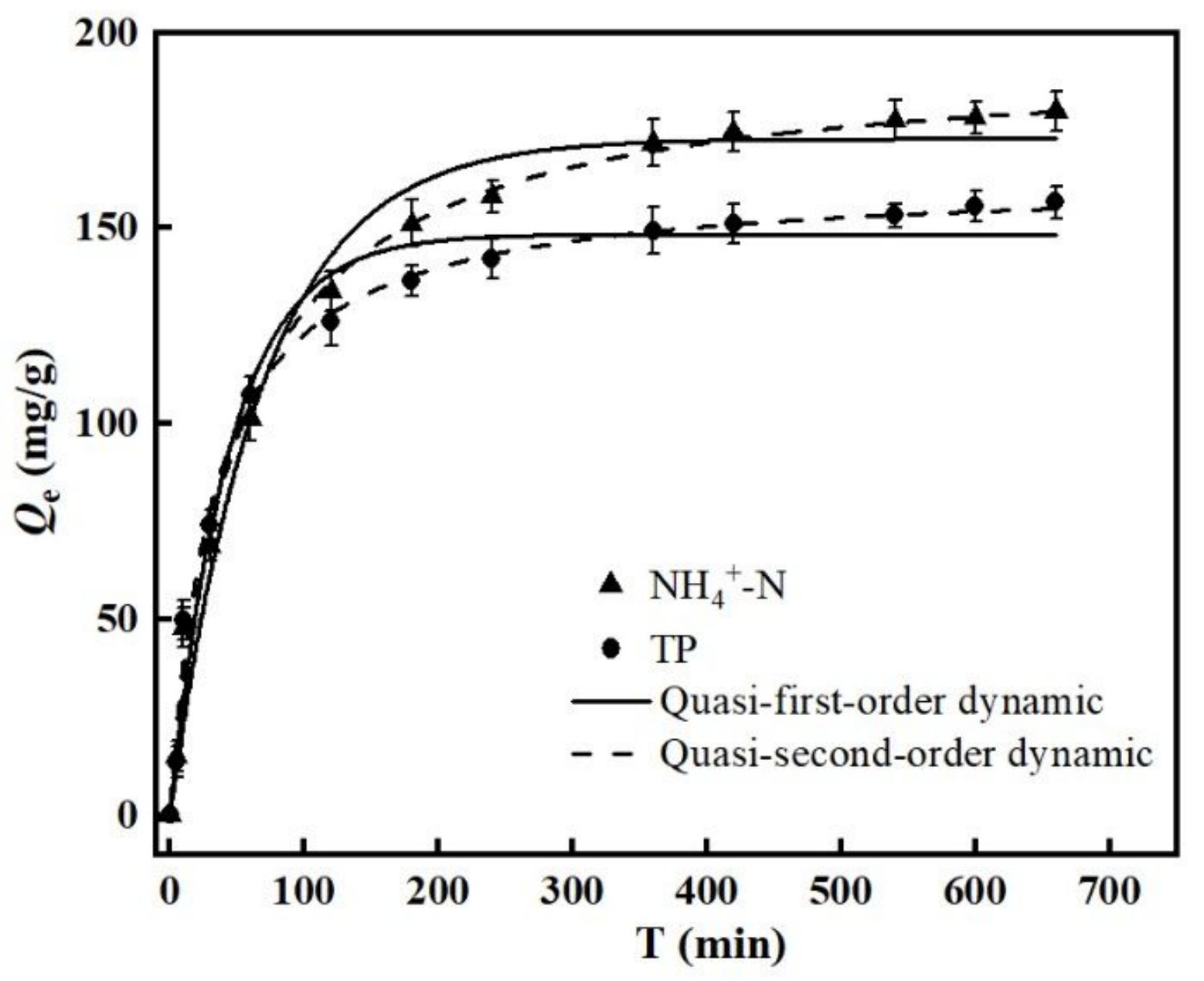

Figure 7

Comparison of kinetic adsorption of ammonia nitrogen and total phosphorus in binary mixed solution 

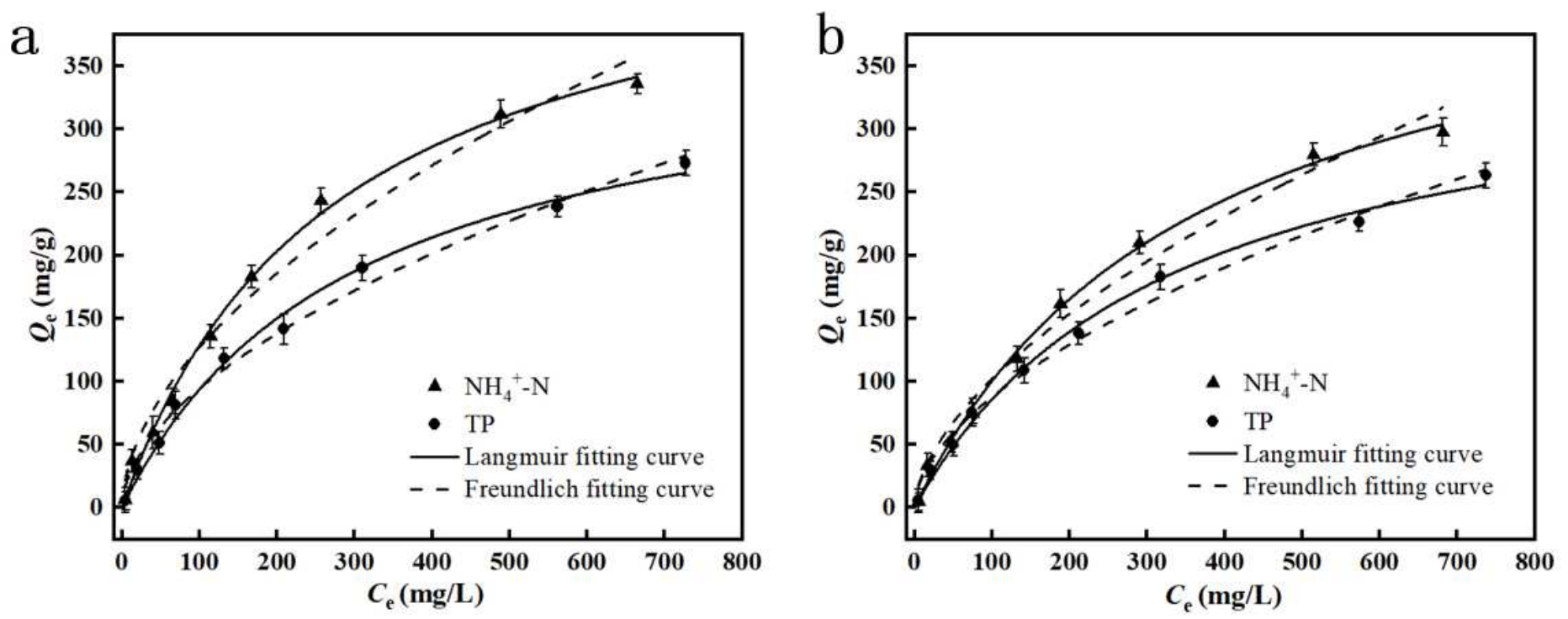

Figure 8

Adsorption isotherm of ammonia nitrogen and total phosphorus ( $\mathrm{a}$ is single-component adsorption, $\mathrm{b}$ is the competitive adsorption)

a

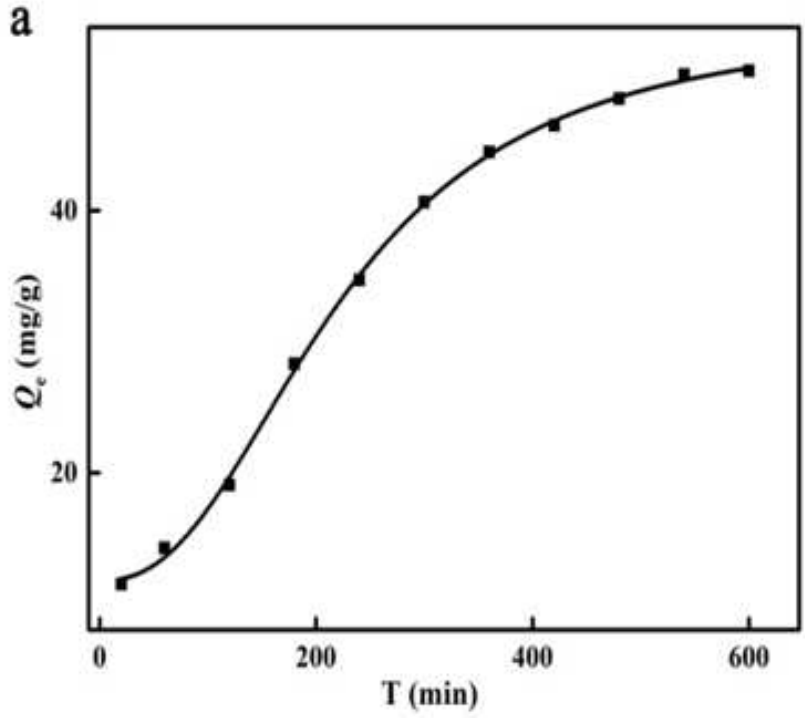

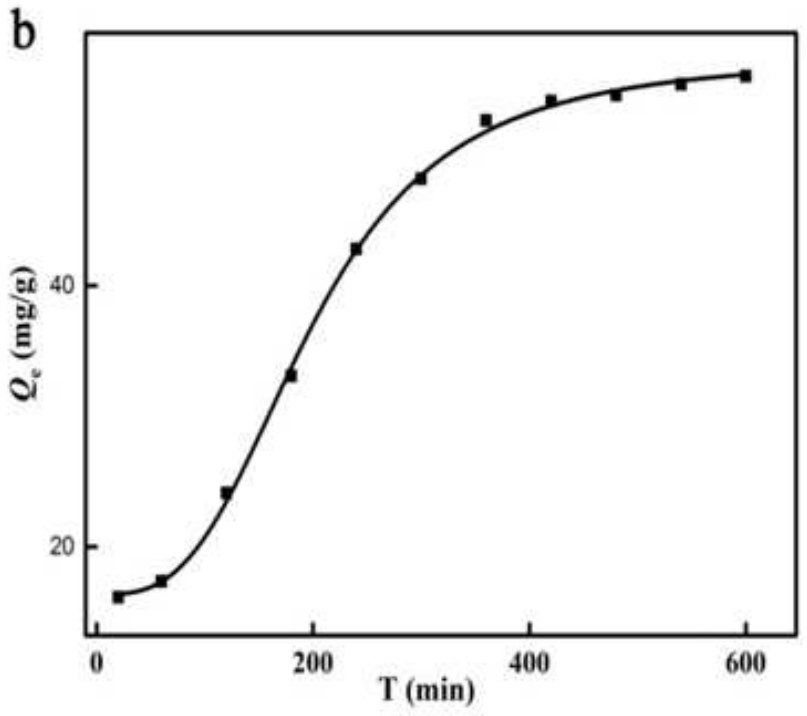

Figure 9

Dynamic adsorption comparisons of ammonia nitrogen and total phosphorus in binary mixed solution (a is the penetration curve of ammonia nitrogen adsorption, $b$ is the penetration curve of total phosphorus adsorption) 


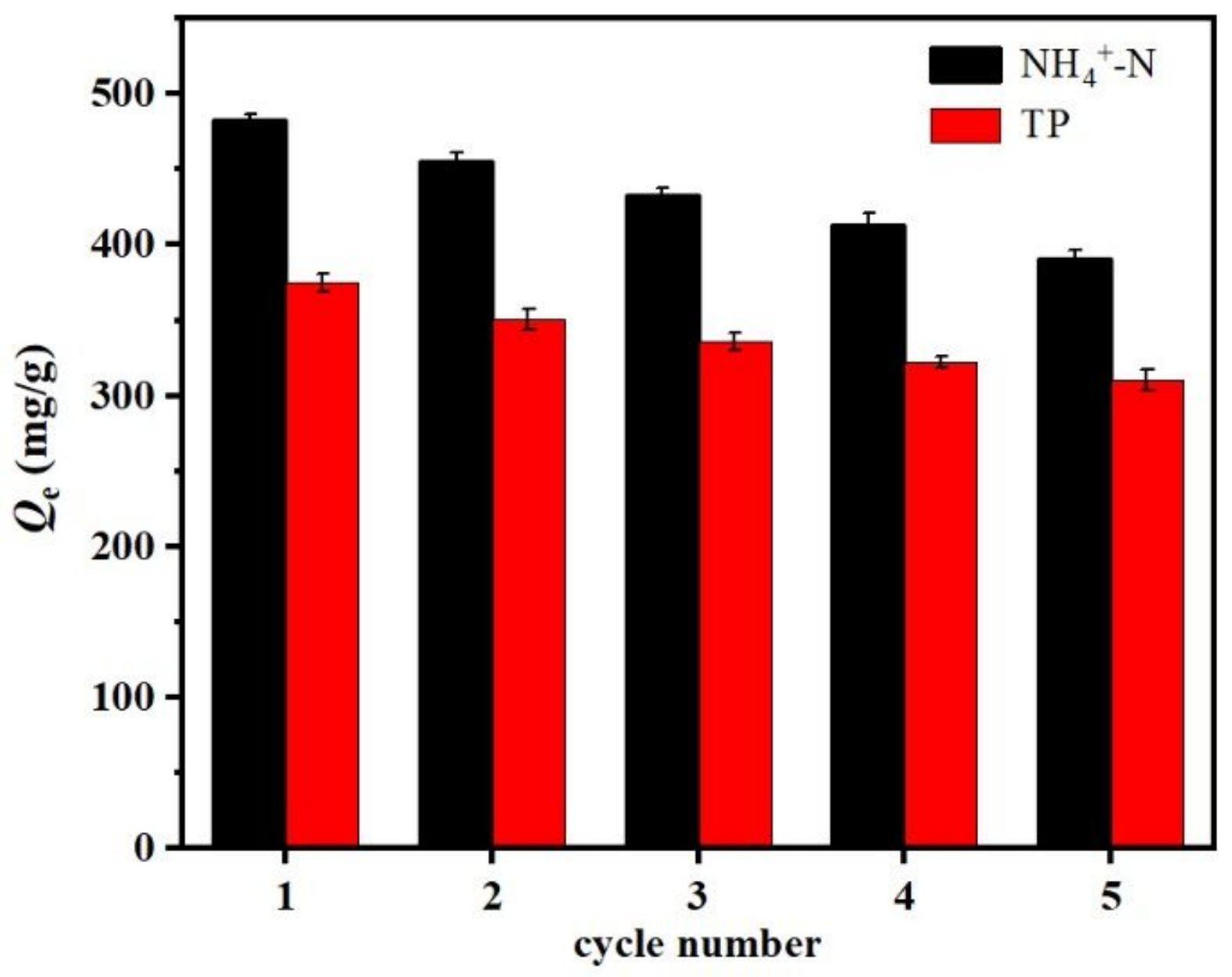

Figure 10

Adsorption capacity of composite membrane over 5 cycles 